\title{
Larvicidal and antimicrobial activities of silver nanoparticles synthesized using marine fluorescent pseudomonads
}

\author{
Shanmugaiah Vellasamy ${ }^{1 *}$, Harikrishnan Hariharan', TS Venkatesh², Mani Jayaprakashvel ${ }^{3}$ \\ From 2nd International Science Symposium on HIV and Infectious Diseases (HIV SCIENCE 2014) \\ Chennai, India. 30 January - 1 February 2014
}

\section{Background}

Research on nanoparticles opens up newer avenues for unraveling various biological challenges including the control of infectious diseases. The present investigation has been aimed to study larvicidal and antimicrobial activities of silver nanoparticles (AgNP's) synthesized using marine fluorescent pseudomonads.

\section{Methods}

In the present study, marine fluorescent pseudomonads were screened against various human pathogenic bacteria and plant fungal pathogens. An autolyzed cell free culture filtrate of selected isolate was used for the synthesis of silver nano particles and characterized using UV, FTIR, XRD and AFM analysis. The antimicrobial efficiency along with larvicidal activity of the synthesized nanoparticles was carried out by observing the lifecycle of mosquito for 96 hours along with appropriate controls.

\section{Results}

Atomic microscopic observation showed that the particle size ranges from 10-100nm. The peaks in UV spectrum clearly indicate that the particles are in the nanoregime. FTIR measurements explained the reduction of silver ions and stabilization of silver nanoparticles. At 96 hours, $60 \%$ mortality observed in test, while only $10 \%$ mortality observed in the control. AgNP's showed significant activity against tested human pathogens and plant fungal pathogens.

\section{Conclusion}

With the suppression of growth of filarial nematode in the larval stage, AgNP's has the potential in eradicating this vector borne disease. It is clear that this isolate can be used to synthesize bioactive nanoparticles efficiently in an eco friendly and cost effective manner besides the fact that it can be used for the control of human and plant pathogenic microbes.

\section{Authors' details}

'Department of Microbial Technology, School of Biological Sciences, Madurai Kamaraj University, Madurai-625021, India. ${ }^{2}$ Department of Biotechnology, Anna University of Technology, Tiruchirappalli-620024, India. ${ }^{3}$ Department of Biotechnology, AMET University, Kanathur, Chennai-603112, India.

Published: 27 May 2014

doi:10.1186/1471-2334-14-S3-P25

Cite this article as: Vellasamy et al:: Larvicidal and antimicrobial activities of silver nanoparticles synthesized using marine fluorescent pseudomonads. BMC Infectious Diseases 2014 14(Suppl 3):P25.

Submit your next manuscript to BioMed Central and take full advantage of:

- Convenient online submission

- Thorough peer review

- No space constraints or color figure charges

- Immediate publication on acceptance

- Inclusion in PubMed, CAS, Scopus and Google Scholar

- Research which is freely available for redistribution

Submit your manuscript at www.biomedcentral.com/submit
() Biomed Central

'Department of Microbial Technology, School of Biological Sciences, Madurai Kamaraj University, Madurai-625021, India

Full list of author information is available at the end of the article 